ROCZNIK ADMINISTRACJI PUBLICZNEJ 2018 (4)

ARTYKUŁY Polityki publiczne / Public Policies

DOI 10.4467/24497800RAP.18.011.9226

http://www.ejournals.eu/RAP/

ISSN 2449-7800 (online), ISSN 2449-7797 (druk), s. 200-209

RICHARD GEFFERT $^{1}$

\title{
Social Justice and Old-Age Pension Adjustment Mechanisms in the Slovak Republic and the Czech Republic between 2016 and 2018
}

\section{Introduction}

Being a complicated variable fundamental phenomenon, social justice is identifiable in the diapason of the western civilisation's social policy in many ways thanks to various indicators ${ }^{2}$. It is a poly-paradigmatic phenomenon that changes in time and space. It is greatly dependent on its understanding by political entities that exercise power as part of the state mechanism given. It is mainly the matter of their axiological basis, according to which the tools to reach their goals (global as well as partial) are selected. Based on the typology of social policy by R. Titmuss or M. Večera ${ }^{3}$, the centre-left political part of the spectrum is perceived as more benevolent as regards social benefit adjustment (not indexing) and as offering an acrossthe-board increase to the beneficiaries than the centre-right political part of the spectrum, where individual entities usually put emphasis on the performance and credits of pensioners (testing incomes). Currently, it can be stated that the traditional classification of beneficiaries is greatly questionable, even when solving social issues from the pragmatic perspective of the best electoral results possible. The right-wing part of the spectrum tries to act as the left-wing counterpart in social matters and the left-wing part of the spectrum favours right-wing solutions concerning private ownership, which is evident in the agenda of relevant political entities ${ }^{4}$.

${ }^{1}$ Assoc. Prof. PhDr. Richard Geffert, Ph. D., Department od Public Policy and Theory of Public Administration, Faculty of Public Administration, Pavol Jozef Šafárik University in Košice, Popradská 66, 04132 Košice, Slovak Republic.

${ }^{2}$ R. Geffert, Sociálna politika a jej axiologické orientácie, Košice: UPJŠ 2014, p. 82.

${ }^{3}$ V. Krebs, Sociálna politika, Praha: ASPI 2005, p. 53.

${ }^{4}$ R. Geffert, Empirická analýza preferencií hodnôt politicko-ideologických paradigiem ako predikátorov rozhodovania sa vo volbách, „Sociálne a politické analýzy" 2007, Vol. 1 (2 January 2018). 


\section{Axiological Orientations of Social Policy Related to Pension Adjustment in Slovakia and Czechia}

In the period subject to review, i.e. between 2016 and 2018, the following political parties have formed the national coalition holding power in Slovakia: SMER-SD, SNS, MOST-HIID; these may be characterised as a coalition of a wide range of values, in which each of the participants builds on a strong social pillar of their political agenda; this could also be seen in the government manifesto of the coalition under review (for more information see the 2016-2020 Manifesto of the Government of the Slovak Republic). As to the government of the Czech Republic, it was formed by the following political parties in the period subject to review: ČSSD, ANO, KDU-ČSL; from social perspective, these may be characterised both axiologically and more broadly. As regards the value orientation of the social policy, this can be found in the document called '2014-2016 and 2018 Manifesto of the Government of the Czech Republic'. There was a parliamentary election in Czechia on 20-21 October 2017. On 13 December 2017, a new minority government was sworn in the office by the president Miloš Zeman; the government, however, did not have the trust of the Chamber of Deputies of the Czech Republic at the time the paper was written (January 2018). Finding a solution to the complicated political situation is currently aggravated by the presidential election. As to the subject and review of the paper objective, this problem is irrelevant considering the time limit of the years 2016-2018 since the 2018 state budget of the Czech Republic has been approved and pensions have already been adjusted. The full names and the basic value orientation of the governmental coalition entities can be found in Table 1.

Table 1. Governmental Political Subjects of the Slovak Republic and the Czech Republic 2016, 2017

\begin{tabular}{|c|c|c|}
\hline Political Subject & Full Name & Basic Axiology \\
\hline SMER-SD & $\begin{array}{l}\text { SMER - Sociálna } \\
\text { demokracia/ } \\
\text { SMER - Social } \\
\text { Democracy }\end{array}$ & $\begin{array}{l}\text { Social Democracy, Social } \\
\text { Populism, } \\
\text { Pro-Europeans, } \\
\text { Left-Wing Nationalism, } \\
\text { Middle-Class }\end{array}$ \\
\hline SNS & $\begin{array}{l}\text { Slovenská národná } \\
\text { strana/ } \\
\text { Slovak National Party }\end{array}$ & $\begin{array}{c}\text { Nationalism, } \\
\text { Right-Wing Populism, } \\
\text { Economic Nationalism, } \\
\text { Euroskepticism, } \\
\text { National and Social } \\
\text { Conservatism, Right }\end{array}$ \\
\hline MOST-HÍD & $\begin{array}{l}\text { Most-občianska strana/ } \\
\text { Most-Civic Party }\end{array}$ & $\begin{array}{l}\text { Liberalism, Liberal } \\
\text { Conservatism, Prosperity, } \\
\text { Political Centre to Centre }\end{array}$ \\
\hline
\end{tabular}




\begin{tabular}{|c|c|c|}
\hline ČSSD & $\begin{array}{c}\text { Česká strana sociálně } \\
\text { demokratická/ Czech } \\
\text { Social Democratic Party }\end{array}$ & $\begin{array}{c}\text { Keynes, Social } \\
\text { Democracy, } \\
\text { Pro-Europeanism, } \\
\text { Middle Ages }\end{array}$ \\
\hline \multirow{2}{*}{ ANO } & $\begin{array}{c}\text { Akce nespokojených } \\
\text { občanů/Events of } \\
\text { Dissatisfied Citizens }\end{array}$ & $\begin{array}{c}\text { Centrism, Liberalism, } \\
\text { Populism, Middle to } \\
\text { Middle }\end{array}$ \\
\hline KDU-ČSL & $\begin{array}{c}\text { Křestanská } \\
\text { a demokratická unie - } \\
\text { Československá strana } \\
\text { lidová/Christian and } \\
\text { Democratic Union - } \\
\text { Czechoslovak People's } \\
\text { Party }\end{array}$ & $\begin{array}{c}\text { Regionalism, } \\
\text { Middle-Law, } \\
\text { Cocial Conservatism, } \\
\text { Christian Democracy, } \\
\text { Pro-European Politics }\end{array}$ \\
\hline
\end{tabular}

Source: Political Agendas of Political Subjects, modified by the author.

The issue of old-age pensions is a complicated topic and includes a wide range of partial legislative amendments $\mathrm{s}^{5}$ concerning individual targets and groups. That is why the attention is going to be drawn to the majority group of pensioners (old-age pensioners only). The paper does not monitor the pension income differences between the sexes (which actually exist). Moreover, the period under review is relatively short (2016, 2017 and 2018). Still, it is relevant in terms of the achievement of the paper objective.

In the first year, it is necessary to quantify the numbers of old-age pensioners in the both states and the volumes of the old-age pensions paid while considering certain specifics of the selected monitored states. On 30 November 2016, there were $1,061,138$ pensions paid to the total number of $1,387,174^{6}$ pensioners in Slovakia with its total number of inhabitants amounting to 5,427,917 (as on 31 March 2016) ${ }^{7}$. On the 30 June 2017, there were $2,396,032$ old-age pensions paid to the total number of 3,504,721 pensioners in Czechia with its total number of inhabitants amounting to $10,578,800$ (as on 31 December 2016) ${ }^{8}$.

In 2015, the average amount of the old-age pension paid in Slovakia was $€$ 400.84, in 2016: $€ 405.78$ and in 2017: $€ 417.57$, respectively 9 . In 2015, the average amount of the old-age pension paid in Czechia was as follows:

${ }^{5}$ J. Ondrová, Abstraktná kontrola ústavnosti právnych predpisov pred Ústavným súdom Slovenskej republiky a Ústavným súdom Českej republiky, Banská Bystrica: Belianum 2016, Banská Bystrica: UMB, 2016.

${ }^{6}$ Social Insurance Agency in Slovakia, Pensions, http://www.socpoist.sk/dochodkove-poistenie-qcg/48006s (16 January 2018).

${ }^{7}$ Government Office of the Slovak Republic, Basic Informations, http://www.vlada. gov.sk/slovensko/ (16 January 2018).

${ }^{8}$ Czech Social Security Administration, Old-age pension, http://www.cssz.cz/cz/ duchodove-pojisteni/davky/starobni-duchody.htm (16 January 2018).

${ }^{9}$ Average amount of paid pensions (in months), http://www.socpoist.sk/priemerna-vyska-vyplacanych-dochodkov--v-mesiacoch-/1600s (16 January 2018). 
CZK 11,300 (€ 442.44), in 2016: CZK 11,422 (€ 447.22) and in 2017: CZK $11,807(€ 462.29)^{10}$.

Table 2. Old-Age Pensions in the Slovak Republic 2016

\begin{tabular}{|l|c|}
\hline \multicolumn{1}{|c|}{ Old-Age Pension } & Number of Persons \\
\hline from 76 euros & 2,477 \\
\hline 76.10 eur -110 euros & 3,267 \\
\hline 100.10 eur -200 euros & 18,690 \\
\hline 200.10 eur -305 euros & 87,496 \\
\hline 305.10 eur -415 euros & 329,994 \\
\hline 415.10 euros -515 euros & 174,288 \\
\hline 515.10 euros -605 euros & 68,158 \\
\hline 605.10 euros -705 euros & 35,873 \\
\hline 705.10 euros -800 euros & 15,721 \\
\hline 800.10 euros -900 euros & 8,595 \\
\hline 900.10 euros $-1,000$ euros & 4,653 \\
\hline 1.000 .10 euros & 3,605 \\
\hline
\end{tabular}

Source: Social Insurance Agency in Slovakia, modified by the author.

Table 3. Old-age Pensions in the Czech Republic 2016

\begin{tabular}{|l|c|}
\hline \multicolumn{1}{|c|}{ Old-Age Pension } & Number of Persons \\
\hline from 352.39 euros -391.50 euros & 250,544 \\
\hline 391.54 euros -430.66 euros & 299,932 \\
\hline 430.70 euros -469.81 euros & 287,615 \\
\hline 469.85 euros -508.97 euros & 253,497 \\
\hline 509.00 euros -548.12 euros & 188,133 \\
\hline 1.566 .17 euros $-3,523.88$ euros & 96 \\
\hline 3.915 .43 euros & 1 \\
\hline
\end{tabular}

Source: Czech Social Security Administration, Conversion to the euro, exchange rate 25,54 $\mathrm{CZK}=1 €$, modified by the author.

Of course, we can neither absolutize nor relativize in terms of such a complicated sphere of social security. It is mostly the identification of an understating of the social justice principle through selected indicators. The legislation concerning the calculation of pensions and economic indicators is different in either of the reviewed states. However, until 31 December 1992, the now unitary state, Slovakia and Czechia, were a federation (until 1990 the Czechoslovak Socialist Republic) where the standard of living of the inhabitants was the same. It is therefore interesting to follow the development of several social and economic indicators having a direct effect on the standard of living currently experienced in both countries in question.

${ }^{10}$ Czech Social Security Administration, Old-age pension, http://www.cssz.cz/cz/ duchodove-pojisteni/davky/starobni-duchody.htm (16 January 2018). 
The attention will be also drawn to the adjustment mechanism in the both states in individual years 2016, 2017 and 2018 in terms of the actual increase in financial benefits, in this case old-age pensions, which were approved by government representatives in Slovakia and Czechia.

Since 1 January 2016, the old-age pensions were adjusted in Slovakia by a fixed amount of $€ 1.90$. As of 1 January 2017, the old-age pensions further increased by a fixed amount which was, compared to 2016, determined as at least $2 \%$ of the average monthly amount of a given kind of pension. In terms of numbers, the amount was $€ 8.20$. The fixed increase was not determined based on the amount of the pension paid but on the basis of the average monthly amount of a given pension kind derived from the average monthly amounts of the pensions valid on 30 June 2016. 2018 has brought a change in the adjustment of the pensions in the Slovak Republic; this adjustment is based on the monitoring of pension inflation. Most of the pensions have increased by $€ 8.40$. As for the pensions higher than $€ 1.150$, these increased in percentage, i.e. by $0.8 \%$, which represented $€ 9$ in total (this increase covers as few as 4.181 old-age pensioners).

In 2016, the pension increased by CZK 40.0, i.e. $€ 1.57$ in the Czech Republic. As can be seen, the principle is similar and based on an across-the board increase by a fixed amount just like in the Slovak Republic in 2016, yet, without the implementation of a percentage-based increase. The adjustment only copied the index of consumer price growth and the growth of earnings. On 1 January 2017, a new model of adjustment was introduced in Czechia, in which the basic valuation of the pension increased by CZK $110(€ 4.31)$ and the percentage valuation by $2.2 \%$ (in a simplified fashion, this is directly dependent on the period of security (deduction) payment and on the income or, more precisely, on the amount of one's own taxable income, which includes the past incomes recalculated so as to reflect the current situation). In terms of the old-pension adjustment, 2018 is characterised by the fact that the pension increase is derived from the increase in actual earnings (in the amount of 50\%) and it does not consider the inflation rate (unlike in the preceding years); instead, the increase in the elderly population's costs of living is taken into account. The basic pension valuation has increased by CZK 150 ( $€$ 5.87). In percentage terms, the valuation has increased by $3.5 \%$.

Despite a significant simplification of the analysed economic indicators, the following can be stated:

Social justice, as one of the basic phenomena of social policy and one forming the basis of the social pillar of all coalition parties' political agenda is exclusively anthropocentrically oriented. As indicated above, the content of the analysed phenomenon, as one of the fundamental principles of social policy, can be identified in many different ways. The substantive fundamentals of social justice are directly dependent on the understanding of the 
entities applying such justice in order to solve particular social challenges. In principle, there can be three basic models outlined in relation to social justice. These can be also applied for the calculation of old-age pensions. The typology is performed on the basis of the primary responsibility for one's own social situation and on the basis of the obligation to resolve the payment of social benefits and to ensure the social security of the population. It is identified based on the extent to which the state, as the basic entity of social policy, participates in the satisfying of needs, i.e. the payment of national social benefits.

In the diapason of social policy, the first model can be defined as redistributing, socialist, social-democratic, or left-wing even. Across-theboard allocation of social benefits (often without any strict income testing) is characteristic of this model. Its grounds related to pensions arise from across-the-board fixed amount adjustment regardless of the pension amount or the number of years worked. The given model of pension increase is closer to the value system preferred by the centre-left and leftwing political entities/parties ${ }^{11}$.

The second model of pension adjustment corresponds to the type of social policy also known as corporate or performance-based. It is a combination of the across-the-board and percentage methods of adjustment, where a part of the pension amount is determined based on the across-theboard principle and the second part is calculated on the basis of a personal pay rating (from which the ratio of personal taxable income is derived). This model is mostly preferred by the political entities from the centre or centre-right part of the political value spectrum ${ }^{12}$.

The third model of pension adjustment, which might resemble the model of residual social policy, is based almost exclusively on the activity of beneficiaries during their economically active life periods. The oldage pension amount is in this case derived from the earnings/income level which a person reached while working. This model of adjustment is typical for the parties from the right-wing part of the political spectrum ${ }^{13}$.

The above-presented models of old-age pension adjustment arise from the typology by R. Titmuss, which has been used as a model since 1974 in most OECD states. Naturally, the issue of pensions, or old-age pensions to be more precise, is very complicated and specific for each and every state. It is not only economics and policy that influence the form of the pension system used. The system is also defined by habits, traditions, culture, religion, demographic development, the characteristics and structure of population, level of education, mentality and other phenomena. The above-mentioned systems are only high-level models which can be freely combined in terms

${ }^{11}$ R. Geffert, Sociálna politika a jej axiologické orientácie, Košice: UPJŠ 2014, p. 101-102.

12 Ibidem, p. 103.

${ }^{13}$ Ibidem, p. 104-105. 
of their potential single-pillar, two-pillar or three-pillar pension scheme. (In the context of the long-term ex-ante solving of the Slovak state's solvency, there has been a three-pillar model since 2005: Pillar 1 - obligatory; continuous, represented by the Social Security Authority, Pillar 2 - capitalised, represented by private pension fund management companies and Pillar 3 - represented by supplementary pension schemes; this model is not subject to review as the payment of pensions from this pillar has not been relevant to date). The specifics can be seen in the above-mentioned partial secondary analysis of outputs/deliverables of the Slovak Statistical Office and the Czech Social Security Administration authority.

On the basis of the structure of government coalitions in the Slovak Republic, there has been the shift from the redistributing model noted (until 2016, the power was in the hands of the 'single-colour' SMER-SD government representing a centre-left political entity). After the 5 March 2016 election, a new government coalition was formed comprising SMER-SD, SNS, MOST-HÍD and SIEŤ (which basically broke up and the coalition currently consists of the three remaining political parties). Compared to the across-the-board model of adjustment introduced on 1 January 2016 as the result of the 2015 social policy by SMER-SD, the adjustment slowly moved (even if only slightly) closer to the specification of the performance-based model. This shift is, however, still only symbolic and touches upon a very small number of the population concerned (the old-age pensions higher than $€ 1,050$ increased in percentage, and this percentage increase by $0.8 \%$ only influenced 4.181 old-age pensioners). Since the formation of the government coalition in 2016, the models of the thirteenth pension and the fourteenth pension have been subject to discussions mostly initiated by the right-wing SNS.

As early as 2015, a strong position of ČSSD can be seen in Czechia, which showed a method of across-the-board pension adjustment. However, as it was losing support, Social Democratic representatives decided to introduce changes in the pension scheme adjustment, all that on behalf of performance and credits (even though it can be stated that when looking at the adjustment mechanism more broadly, it only resulted in minor differences). The shift from the redistributing model to the performance-based model can be seen there. (In 2013, the government coalition consisting of ODS, TOP 09 and VV enforced a pension scheme reform, which was later invalidated by the new government consisting of ČSSD, ANO and KDU - ČSL. Pillar 2, as the main part of the pension scheme in Czechia was cancelled once for all. There have been efforts to boost the popularity of the third pillar, i.e. the former supplementary pension scheme in which even children can start saving or their parents can do so for them until the age of 18.) 
Table 4. Governmental Political Subjects in 2010-2013

\begin{tabular}{|c|c|c|}
\hline Political Subject & Full Name & Basic Axiology \\
\hline ODS & $\begin{array}{c}\text { Občianska demokratická } \\
\text { strana/ } \\
\text { Civic Democratic Party }\end{array}$ & $\begin{array}{c}\text { Liberalism, Conservatism } \\
\text { Economic Liberalism, } \\
\text { Liberal Conservatism } \\
\text { Political right }\end{array}$ \\
\hline TOP 09 & $\begin{array}{c}\text { Tradice Odpovědnost } \\
\text { Prosperita/Tradition } \\
\text { Responsibility Prosperity }\end{array}$ & $\begin{array}{c}\text { Liberal and Fiscal } \\
\text { Conservatism, Christian } \\
\text { Democracy, Political Right }\end{array}$ \\
\hline VV & Věci veřejné/ Public & $\begin{array}{c}\text { Liberalism, National } \\
\text { Affairs }\end{array}$ \\
& Centre-Right \\
\hline
\end{tabular}

Source: Political Agendas of Political Subjects, modified by the author.

\section{Conclusion}

The objective of the paper is to establish the substantive basis of the 'social justice' phenomenon in social policy and its understanding by the government representatives in Slovakia and Czechia considering the 20162018 time horizon. In terms of its content, the limit of this fundamental principle of social policy was monitored through economic mechanisms of the old-age pension adjustment and by law, with the legislation-enshrined date of 1 January of the calendar year, one of the two basic dates of the social security adjustment. It has been discovered that, despite axiological differences related to the declaration and performance of goals of individual political entities or their coalitions, it is currently possible to identify basic models of the instruments applied by centre-right and centre-left political groupings; all that in terms of the pragmatism concerning the achievement of the best parliamentary election results possible. They are to result in the establishment of a certain social security model moving from a redistribution to a residual form. When it comes to the amount of old-age pensions in both states, only very slight differences can be seen. Looking at the given issue from the global and significantly simplified perspective, it has been discovered that the political entities showing the values recognised by the centre to the left part of the political spectrum prefer the old-age pension adjustment based on a fixed amount for all old-age pensioners, regardless of their performance during their economically active life period and of the number of the years worked. The political entities axiologically identified in the right and centre-right part of the political spectrum are interested in the adjustment on the basis of percentage of the pension awarded. Here, the quality of education and the level of income during the economically-active period of life and the number of worked or additionally worked years are preferred for the purpose of old-age pension calculation. The analysis of social justice as one of the key principles of the western civilisation's social 
policy has shown that the understanding of the given phenomenon is relative to a great extent and the 'panta rhei' change in time and space is of dynamic nature and does not always respond to the needs of the beneficiaries, i.e. receipients, in an adequate manner. Moreover, the analysis depends on the preferences of governmental political entities executing social policy, including social security policy. The economic dimension and fiscal policy are also always considered. However, social and political influence is of priority.

\section{Bibliography}

Czech Social Security Administration, http://www.cssz.cz/cz (16 January 2018).

Czech Social Security Administration, Old-age pension, http://www.cssz.cz/cz/ duchodove-pojisteni/davky/starobni-duchody.htm (16 January 2018).

Czech Statistical Office, https://www.czso.cz/ (05 January 2018).

Geffert R., Sociálna politika, Košice: UPJŠ 2009.

Geffert R., Empirická analyza preferencií hodnôt politicko-ideologických paradigiem ako predikátorov rozhodovania sa vo volbách, „Sociálne a politické analýzy” 2007, Vol. 1 (January 2018).

Geffert R., Sociálna politika a jej axiologické orientácie, Košice: EQUILIBRIA 2014.

Government Office of the Slovak Republic, http://www.vlada.gov.sk/ (16 January 2018).

Government Office of the Slovak Republic, Basic Information, http://www.vlada. gov.sk/slovensko/ (16 January 2018).

Government of the Czech Republic, https://www.vlada.cz/ (5 January 2018).

Krebs V., Sociální politika, Praha: ASPI 2005.

Ondrová J., Abstraktná kontrola ústavnosti právnych predpisov pred Ústavným súdom Slovenskej republiky a Ústavným súdom Českej republiky, Banská Bystrica: UMB 2016.

Priemerná výška vyplácaných dôchodkov (v mesiacoch), http://www.socpoist.sk/ priemerna-vyska-vyplacanych-dochodkov--v-mesiacoch-//1600s (16 January 2018).

Programové vyhlásenie vlády Slovenskej Republiky 2016-2020, http://www.vlada.gov.sk/programove-vyhlasenie-vlady-sr-na-roky-2016-2020/ (10 January 2018).

Programové prohlášení vlády České Republiky, https://www.vlada.cz/cz/media- centrum/dulezite-dokumenty/programove-prohlaseni-vlady-cr-115911/ (10 January 2018).

Social Insurance Agency in Slovakia, http://www.socpoist.sk/ (16 January 2018).

Social Insurance Agency in Slovakia, Pensions, http://www.socpoist.sk/dochodkove- poistenie-qcg/48006s (16 January 2018).

Statistical Office of the Slovak Republic, https://slovak.statistics.sk/ (6 January 2018).

Titmuss R., Social Policy. An Introduction, London: Allen \& Unwin 1974.

Večeřa M., Sociální stát, Praha: Slon 1996. 
Zákon č. 333/2017 Z. z. Zákon o štátnom rozpočte, http://www.Zakonypreludi.sk/ zZ/2017-333 (23 December 2017).

Zákon ze dne 19. Prosince 2017 o státním rozpočtu České republiky na rok 2018, https://www.epravo.cz/mz/zakon-ze-dne-19-prosince-2017-o-statnim-rozpoctu-ceske-republiky-na-rok-2018-22007.html (19 December 2017).

Abstract

Social justice as one of the essential complex principles of state social policies is a considerably relative phenomenon, which can be considered and explained in a variety of ways depending on time and place. This research paper deals with the content structure of the phenomenon of social justice from the point of view of the social, political and economic particularities of theory and practice of axiological systems of the western civilisation. The main aim of the article is to identify the comprehension of social justice by dominant government milieus of Slovakia and Czechia by means of adjustment devices applied to old-age pensions over the observed period.

Keywords: old-age pension, social security, state, Slovak Republic, Czech Republic

\section{Sprawiedliwość społeczna i narzędzia dostosowywania wysokości świadczeń emerytalnych na Słowacji i w Czechach w latach 2016-2018}

Streszczenie

Sprawiedliwość społeczna, jako jedna z kluczowych złożonych zasad społecznej polityki państwa, to w znacznej mierze zjawisko względne, które można różnie umieszczać w czasie i przestrzeni. Niniejszy artykuł badawczy skupia się na merytorycznej strukturze zjawiska sprawiedliwości społecznej z punktu widzenia specyfiki społeczno-polityczno-gospodarczych teorii i praktyki aksjologicznych systemów cywilizacji zachodniej. Głównym celem artykułu jest opis rozumienia sprawiedliwości społecznej przez dominujące grupy rządzące na Słowacji i w Czechach na drodze analizy mechanizmów dostosowawczych w zakresie wysokości emerytur w latach 2016-2018.

Słowa kluczowe: emerytura, zabezpieczenie społeczne, państwo, Słowacja, Czechy 